\title{
SELF-ESTEEM DEVELOPMENT OF VOCATIONAL HIGH SCHOOL STUDENTS IN INDONESIA: DOES GROUP COUNSELING WITH ASSERTIVE TRAINING TECHNIQUE HELP?
}

\author{
Nandang Rusmana*, Anne Hafina, Riesa Rismawati Siddik, Lutfi Nur \\ Universitas Pendidikan Indonesia, Indonesia \\ *e-mail: nandangrusmana@upi.edu
}

\begin{abstract}
Self-esteem contributes to an individual's mental health and quality of life because it determines who they are, activities they do, as well as their personality. This study aimed to describe the development of students' self-esteem through group counselling intervention with an assertive training technique. Employing a true experimental method with the pretest-posttest control group design, this study involved 191 students as the samples following Isaac and Michael at an error level of 5\% of the total population of 420 students. From the self-esteem questionnaires, it was found that 28 students belonged to the low self-esteem group. Then, interventions were carried out in six sessions outside of class hours, with a duration of 90 minutes for each session. The data were obtained through the Coopersmith Self-Esteem Inventory (CSEI) instrument with a reliability value of .92, and analyzed using the Mann-Whitney two mean discrimination test. The results showed that students who were given group-counselling interventions with assertive training technique were better than those in the control group. Therefore, assertive training technique helps restore students' awareness of their rights to have a happy and esteemed life. Besides, assertive training technique helps renew students' confidence in the functioning of their minds and belief in their abilities in facing life challenges.
\end{abstract}

\section{Keywords: assertive training, group counseling, self-esteem, vocational high school student}

\section{PENGEMBANGAN HARGA DIRI SISWA SEKOLAH MENENGAH KEJURUAN DI INDONESIA: APAKAH BIMBINGAN KELOMPOK DENGAN TEKNIK ASSERTIVE TRAINING MEMBANTU?}

\begin{abstract}
Abstrak: Harga diri memiliki peran pada kesehatan mental dan kualitas hidup seseorang, karena menentukan siapa dirinya, kegiatan yang dilakukannya, serta kepribadiannya. Penelitian ini bertujuan melihat perkembangan harga diri siswa melalui intervensi bimbingan kelompok dengan teknik assertive training. Penelitian menggunakan metode true experiment dengan pretest-posttest control group design. Jumlah sampel penelitian ditentukan dengan merujuk Isaac dan Michael pada taraf kesalahan 5\% dari total populasi 420 siswa, sehingga terpilih sebanyak 191 siswa sebagai sampel. Dari 191 siswa diberikan tes melalui angket harga diri yang hasilnya diperoleh sebanyak 28 siswa terindentifikasi mempunyai tingkat harga diri rendah. Pelaksanaan intervensi dilakukan dalam enam sesi di luar jam pelajaran, dengan durasi waktu setiap sesi selama 90 menit. Data penelitian diperoleh melalui instrumen Coopersmith SelfEsteem Inventory (CSEI) dengan nilai reliabilitas 0,92. Data dianalisis menggunakan uji perbedaan dua rata-rata Mann-Whitney. Hasil penelitian menunjukan bahwa siswa yang diberikan intervensi bimbingan kelompok dengan teknik assertive training lebih baik daripada siswa pada kelompok kontrol. Teknik assertive training membantu mengembalikan kesadaran siswa terhadap hak-hak dirinya untuk dapat hidup bahagia dan berharga. Teknik assertive training juga membantu memperbaharui keyakinan siswa terhadap keberfungsian pikiran dan keyakinan pada kemampuan dirinya dalam menghadapi tantangan hidup.
\end{abstract}

Kata Kunci: harga diri, bimbingan kelompok, assertive training, siswa SMK

\section{INTRODUCTION}

Self-esteem contributes to someone's mental health and quality of life because it determines whom he/she is, the activity conducted, and the personality (Mann, Hosman, Schaalma, \& Vries, 2004). The aspect of selfesteem becomes an important part of a person's development in overcoming problems in his life 
(Yadav \& Iqbal, 2009). The most important task of a person's mental, emotional, and social health, which starts from infancy and continues until he dies, is to build positive self-esteem (Orth, Erol, \& Luciano, 2018). It becomes essential because it is one of the psychological basis of individuals in adjusting to the changes. How individuals interact with their environment and how individuals make social adjustments will be influenced by how they assess their worth. Those who value themselves highly are satisfied with their abilities and feel that they receive positive appreciation from the environment (Widodo \& Pratitis, 2013).

Individuals with high self-esteem can express their feeling that they are "good enough" (Moksnes \& Reidunsdatter, 2019). They will feel that they are valuable ones who can respect and admire themselves but do not expect others to admire them (Algoe \& Haidt, 2009) and have no idea that they are more powerful than others. Conversely, the individuals with low self-esteem will have characteristics including hypersensitivity, insecurity, protective from hurtful things than to actualize opportunities and enjoy life, inability to take risks, symptoms of depression in general, pessimistic, lonely, feelings of alienation, etc. (Murray \& Holmes, 2000; Masselink, Roekel, \& Oldehinkel, 2018).

Low self-esteem is caused by the failure of individuals to communicate interpersonal deeply (Ronningstam, 2017). Increased selfesteem in adolescents can occur if they want and can overcome their problems rather than avoid them. Self-esteem is also influenced by internal communication within the individuals (Andreassen, Pallesen, \& Griffiths, 2017; Cameron \& Granger, 2019). They see themselves as worthy, kind, and valuable if they can link known facts about themselves to the values, and the judgments of others.

There needs to be intervention to increase self-esteem before more severe psychological problems arise, even to the point of causing mental disorders. There are several types of techniques to increase self-esteem. There are some techniques used by previous researchers to improve self-esteem (Murk, 2006), namely: acceptance and positive feedback (Harris, Guo, Mcadams, Garnier-villarreal, \& Trzesniewski, 2017), modeling and problem solving (Bowen, Neill, \& Crisp, 2016), cognitive restructuring
(Obikwelu, 2015), assertiveness training (Kia, Shabani, Ahghar, \& Modanloo, 2016; Parray \& Kumar, 2017), natural self-esteem moments, groups, individual work, and practice.

Of the various techniques available, the assertive training technique from Cognitive Behavioral Therapy (CBT) is the one that is considered superior in developing students' self-esteem. This selection is based on the background that self-esteem is a self-evaluation, and has the essence that lies in the basic negative beliefs about oneself. This basic belief involves cognitive, affective, and behavior. It is cognitive because the person consciously thinks about the difference between the ideal self and the real self. Affective refers to the feelings or emotions a person has when considering those differences and aspects of self-esteem behavior manifested in behaviors such as assertiveness, resilience, being decisive, and respecting others.

Assertive training is a behavioral approach that has the objective of obtaining new behavior by erasing the old (maladaptive) behavior, as well as strengthening and maintaining desired behavior (Newman, LaFreniere, \& Shin, 2017). This technique is popular in a behavioral approach to help students develop social skills to overcome various social problems (Corey, 2009; Radtke, Strege, \& Ollendick, 2020). It is in the form of an exercise given to the individual who is psychologically problematic such as often experiencing anxiety, lack of confidence, and not adaptive, thus hampering his performance (Dehnavi \& Ebrahimi, 2016). This training is a short-term educational process that uses systematic and organized procedures to gain skills in responding to or overcome problematic situations. It can defend personal rights and express thoughts, feelings, beliefs directly, honestly, and in an appropriate manner that is not to hurt or harm themself or others (Rees \& Graham, 1991; DiGiuseppe, Venezia, \& Gotterbarn, 2019). This can happen because the purpose of assertive training technique is to teach the right strategy for people to identify and act on their wants, needs, and opinions while still respecting others (Connelly \& Rotella, 1991; Lynch \& Gussel, 1996).

Several studies mention that assertive training technique has positive impact. Murk (2006) found that assertive training technique proved to be able to increase self-esteem, skill 
in defending personal rights as valuable living things, and belief in students. The provision of these skills can be able to survive and remain productive in dealing with difficult and unfavorable situations such as the poverty cycle experienced by adolescents with low socioeconomic status. This is supported by Akbari, Mohamadi, \& Sadeghi (2012) study of 40 female students at Azad Islamic University using the experimental method with the control group and the intervention group. The results showed that assertive training was effective in increasing the self-esteem and self-confidence of female students. This is in line with Branden's research (1994); Seart (2003); Karagozoglu, Kahve, Koc, \& Adamisoglu (2008); Nesrin, Sukut, Uta, \& Batmaz (2016) which shows that someone who successfully expresses himself will have an impact on increasing self-esteem and reducing anxiety and depression.

Based on the aforementioned discussion, this study aims to describe the development of students' self-esteem through group guidance with assertive training technique in one of State Vocational High School in Indonesia. This is because the previous studies have not discussed about the aspects of the effectiveness of technique in improving the students' selfesteem. Therefore, this study tries to fill the empirical gap in which the present study discuss the detail of the improvements experienced by the students after getting assertive training counseling, and contextual gap in which this present study was conducted in different context involving different participants of research.

\section{METHODS}

The research method uses true-experiment with pretest-posttest control group design. The population in this study were 420 class XI students of a state vocational high school in Bandung, Indonesia, academic year 2017/2018. The reason for taking this population is that vocational high school students with an age range of 15-17 years belong to the category of adolescents who are still in the search for high identity and conformity. Determination of the number of samples carried out by referring to Isaac and Michael at a level of error of 5\% so that as many as 191 students were selected through random sampling technique. Furthermore, 191 students were given tests through self- esteem questionnaires, with 28 students identified as having low self-esteem. Then the number is divided into two groups: 14 students (experimental) and 14 students (control).

The study began by measuring the initial tests using self-esteem questionnaires in the experimental and control groups. The preliminary test is carried out for 45 minutes, before conditioning the group members beforehand to give directions related to the instrument filling instructions in the form of selfesteem questionnaires and explain the purpose of the initial test implementation.

At the core stage, the experimental group was given the treatment of a series of group guidance sessions through assertive training technique outside of class hours. The treatment intervention was delivered in six sessions, carried out twice a week. In this study, the researchers not only acted as experimenters but as counselors who guided intervention sessions.

In the final stage, the final test measurements were conducted again using the same instrument as the initial test, the self-esteem questionnaire. The final test activity was carried out after one week from the last intervention, the purpose of which was to provide time for the output permeation in the form of values obtained from the counseling intervention session in developing student self-esteem. The final test was carried out for 45 minutes after inviting group members to review any changes that had been achieved after the intervention was given, and then explained the instrument filling instructions.

The research instrument used was a selfesteem questionnaire adapted from Coopersmith self-esteem inventory (CSEI). This is based on researchers referring to the theory developed by Coopersmith. Besides, this instrument has been tested for validity and reliability in measuring self-esteem (Coopersmith, 1967). This instrument measures self-esteem in several domains, namely overall, family, social, and academic self-esteem (Ghahramani, Besharat, $\&$ Naghipour, 2011). Before being used for data collection, the instrument was tested in advance with stages: 1) the feasibility test, it aimed to see the suitability of the construct, content, and editorial instruments with a theoretical basis. Three guidance and counseling experts weighed their eligibility. 2) Legibility test, this aimed 
to measure the extent of the readability of the statement items in the instrument so that the purpose or meaning of each statement could be understood easily. 3) Validity and reliability test, this aimed to obtain valid data and ensure that it could measure what should be measured. Besides, concerning the level of constancy/ permanence of the measurement results. The validity and reliability test used the Rasch Model application, which was tested on 60 respondents. The results obtained a reliability value of .92 , meaning that the instrument was valid and reliable so that it could be used in research.

The data analysis technique was done through descriptive statistical methods by looking at the average difference. Data normality test was conducted using a Shapiro-Wilk test analysis. The results were not normally distributed. Furthermore, because the data were not normally distributed, the process to determine the significance was continued using non-parametric statistics using the MannWhitney test with the help of the SPSS release 23.

\section{RESULTS AND DISCUSSION Results}

The results of this study will focus on looking at the self-esteem profile of vocational students and the effectiveness of group guidance with assertive training technique.

\section{Profile of Self-esteem}

Based on the results of data collection, the student self-esteem for the high category was $85.34 \%$ and the low category was $14.66 \%$ as outlined in the Table 1.

Table 1. Profile of Students' Self-Esteem

\begin{tabular}{ccc}
\hline Categories & $\begin{array}{c}\text { Number of } \\
\text { Students }\end{array}$ & Percentage \\
\hline High self-esteem & 163 & 85.34 \\
Low self-esteem & 28 & 14.66 \\
\hline Total & 191 & 100 \\
\hline
\end{tabular}

Based on the Table 1, 28 students were identified as in the low self-esteem category. Furthermore, they were distributed into two groups namely experimental $(N=14)$ and control $(N=14)$.
The Effectiveness of Assertive Training Group Guidance Technique to Increase Student SelfEsteem

Based on non-parametric statistical tests, it was found that the data were not normally distributed. Therefore, the calculation of the hypothesis test employed the Mann Whitney test. The Table 2 and Table 3 are the output of the calculation.

Table 2. Mann Whitney Test Output

\begin{tabular}{llrrc}
\hline & Group & $\boldsymbol{N}$ & $\begin{array}{r}\text { Mean } \\
\text { Rank }\end{array}$ & $\begin{array}{c}\text { Sum of } \\
\text { Rank }\end{array}$ \\
\hline $\begin{array}{l}\text { Assertive } \\
\text { training }\end{array}$ & Experiment & 14 & 19.64 & 275.00 \\
\hline & Control & 14 & 9.36 & 131.00 \\
\hline & Total & $\mathbf{2 8}$ & & \\
\hline
\end{tabular}

Table 3. The Results of $Z$-Score

\begin{tabular}{lr}
\hline & Assertive Training \\
\hline Mann-Whitney U & 26.000 \\
Wilcoxon W & 131.000 \\
$Z$ & -3.321 \\
Asymp. Sig. (2-tailed) & .001 \\
Exact Sig. [2*(1-tailed Sig.)] & $.001^{\mathrm{a}}$ \\
\hline
\end{tabular}

Based on the Table 2, it can be seen that the average score obtained by the experimental group was 19.64 while the control group was 9.36. This means that the average students' selfesteem for experimental group with assertive technique intervention is better than the control group. Furthermore, it can be seen the "Test Statistics" output (see Table 3) is known that the Asymp value. Sig. ( 2 tailed) of .001<.05. Hence, it can be concluded that there are differences in self-esteem of students before and after the intervention of group guidance with assertive training technique. This was also supported from the data obtained from students' daily journal in which there are some students who said, "I will try to express what I feel, I know my weaknesses and strengths, and I become more confident."

\section{Discussion}

The focus of this study was to examine the differences between the experimental and control groups on the development of students' self-esteem. The results stated that the experimental group gave a higher level of 
significance compared to the control group on the development of self-esteem. This result is due to the experimental group was given a deliberate and structured intervention program which was characterized by treatment through group counseling with assertive training technique for students (Bean \& Forneris, 2016; Rokhayati, Nur, Elan, \& Gandana, 2017). The group counseling intervention activities with assertive training technique were carried out for six sessions.

Assertive behavior is the behavior of someone who has confidence and ability to control social interaction. Coopersmith (1967) states self-esteem is an evaluation made by an individual looking at himself, especially regarding the attitude of accepting and rejecting, also an indication of the amount of individual confidence in his ability, the meaning of success and worth. The emergence of assertiveness in adolescents is due to positive self-esteem that can foster the belief that what is done is very valuable, and what is expected by adolescents can be fulfilled by optimizing their abilities. If adolescents are not assertive, they are not able to express their thoughts, feelings, and beliefs about themselves, because they tend not to be able to get out of their problems and in education so that all goals can be achieved, therefore there should be efforts to increase assertive behavior in students.

This research was conducted in a group of 14 students to develop group dynamics that led to an increase in student self-esteem. This is in line with Windaniati (2013); Vatankhah, Daryabari, Ghadami, \& Naderifar (2013) who state that group dynamics can motivate each student to be open and develop himself so that assertive training can grow and improve well the components of student self-esteem include power, significance, virtue, and competence.

Self-esteem is built on attitudes and beliefs about oneself, as Solehuddin \& Budiman (2019) claim as part of multicultural competence. Therefore, Marzuki, Miftahuddin, \& Murdiono (2020) see the importance of multicultural education, one of which aims to develop attitudes and beliefs about themselves and build student awareness of the importance of self-esteem both individual self-esteem and self-esteem in the national context.
The assertive formation is inseparable from the influence of the environment, whether family, community, educational environment, or cultural environment. When the environment provides opportunities for individuals to bring up their assertiveness, individuals will be able to develop their assertiveness. Therefore assertive behavior itself must be developed with a good environment too and from the individual itself (Nur, Nurani, Suryana, \& Ahmad, 2020).

Increasing self-esteem and positive, assertive relationships involve how to explore what matters and the willingness to see things differently. Positive self-esteem gives individuals the courage to act on their intuitions. While negative self-esteem shows worrying behavior. This fear is often based on the past, which they consider negative. As a result, people refrain from being creative, taking risks, or offering help.

Individuals in their lives must be able to place themselves amid reality. The way to place oneself is different from each other. Some individuals deal it with feelings of helplessness (fear). Individuals who deal with reality and powerlessness have a negative response to self. The individuals will always live in fear, which will affect their feelings so that there is a shock in the balance of personality, which is an unstable emotional state.

Guilt feelings have two kinds of things, namely (1) feelings of guilt experienced by individuals for violating their moral values, (2) individuals feel guilty for things that cause fear, for example, parents. Feelings of guilt happen on individuals who have awareness and selfconfidence, or in other words, the individuals have determined the criteria regarding what is good and what is bad for him (Al-hadihasan, Callaghan, \& Lymn, 2017). There is a close relationship between the concept of self-esteem and assertive behavior because self-esteem can produce assertive behavior, and assertive behavior can also affect self-esteem. There is a reciprocal relationship between them (Seart, 2003).

Assertive training is a technique that can be used to change inappropriate individual behavior. The effect on self-esteem is that the level of self-esteem is determined by how to fit one's self-image is with the self-ideal. Assertive 
training was given to research participants to bring the self-ideal closer to the self-image. The participants were trained to respond to situations by behaving or doing something (self-image) according to what they should (self-ideal). Assertive training could train the participants to find out how much they knew themself based on evaluations made by them. The habits of reflection about who express the attitude of accepting or rejecting also indicate the magnitude of the participants' confidence in their abilities, meaningfulness, success, and worth.

In addition, some aspects of self-esteem arise when assertive training technique with group counseling methods are applied. First, a sense of safe/security, the extent to which individuals feel safe in behaving to match what is expected by others and are not afraid to be blamed. Individuals feel confident about the behavior that arises so that individuals do not feel anxious about what happens to him.

Second, a sense of identity, an individuals' awareness of the potential, abilities, and meaning of self. The individuals feel meaningful, loved, and accepted by others. They realize the potential and uniqueness that is owned and aware of the limitations that exist in themselves. Individuals with a strong sense of identity will be able to accept themselves positively, feel worthy, and valuable to get praise.

Third, a sense of belonging, a feeling that arises because the individuals feel like an important figure and are needed by others by being recognized by other groups of people. Individuals with a sense of belonging can be good friends, can work well together, and have a comfortable feeling in a group/peer environment.

Fourth, the sense of purpose, the extent confidence that individuals will succeed in achieving their goals, and highly motivated. This will make individuals have the power to set realistic goals and be able to direct the behavior they want to achieve. They can take the initiative and carry out the plans that have been prepared previously.

Fifth, sense of commitment is the individual has an awareness that the individual can overcome all challenges and obstacles that are faced with the ability to independently. Individuals also have an unyielding attitude in facing various challenges and obstacles.
Therefore, respect for individuals will be significant for their lives in the future. Appreciation of a father, mother, family, friends, and the environment will shape one's self-esteem. The surrounding environment will influence the degree of self-esteem, both from the pattern of care, environment, experience, and socioeconomic of the child's family. Low self-esteem individuals can be aggressive and passive, while high self-esteem can produce assertive personality traits. Assertive training can produce short-term and long-term positive effects, both on these individuals and important people in their lives (Seart, 2003; Kearns, Wright, Abrams, \& Hazley, 2017; Huang, Chen, Greene, Cheung, \& Wei, 2019).

The indicators of achievement in this study can be seen from changes in students' beliefs that lead to a new awareness about patterns or some life decisions that are considered wrong in the past. Students become aware that in the past, they always viewed negative towards themselves, lacking self-respect, lack of strengthening selfability, fear to compete, and lack motivation for life success. This assertive training technique helps restore students' awareness of their rights to live happily, valuable, and worthy of their rights in expressing their needs and desires, as well as their rights to enjoy the results of all that has been attempted. The assertive training technique also helps renew students' confidence in the functioning of their minds and belief in their abilities in facing life's challenges.

\section{ACKNOWLEDGMENT}

With the completion of this article, the gratitude goes to the State Vocational High School (SMK) in Bandung, Indonesia, for providing the opportunity and permission to conduct research.

\section{CONCLUSION}

Group counseling with an assertive training technique is useful in developing students' self-esteem. Through this technique, the students can communicate and solve their problems so that it impacts on conditions of positive self-esteem.

Group counseling with this assertive training technique helps restore student awareness of their rights to live happily, 
valuable, and worthy of their rights in expressing their needs and desires, as well as their rights to enjoy the results of all that has been attempted. Besides, assertive training technique are also useful in helping to renew students' confidence in the functioning of the mind and belief in their abilities in facing life's challenges.

Based on the findings of the study, it is recommended that future studies compare assertive training intervention in group nuances and individual nuances so that the effectiveness, the strengths, and the weaknesses of the two types of interventions can be obtained.

\section{REFERENCES}

Akbari, B., Mohamadi, J., \& Sadeghi, S. (2012). Effect of assertiveness training methods on self- esteem and general self efficacy female students of islamic azad university anzali branch Iran. Journal of Basic and Applied Scientific Research, 2(3), 2265-2269. https://www.textroad.com/ pdf/JBASR/J.\%20Basic.\%20Appl.\%20 Sci.\%20Res.,\%202(3)2265-2269,\%20 2012.pdf.

Al-hadihasan, A., Callaghan, P., \& Lymn, J. S. (2017). Qualitative process evaluation of a psycho- educational intervention targeted at people diagnosed with schizophrenia and their primary caregivers in Jordan. BMC Psychiatry, 17(68), 1-17. https://doi. org/10.1186/s12888-017-1225-2.

Algoe, S. B., \& Haidt, J. (2009). Witnessing excellence in action: The 'other-praising' emotions of elevation, gratitude, and admiration. The Journal of Positive Psychology, 4(2), 105-127. https://doi. org/10.1080/17439760802650519.

Andreassen, C. S., Pallesen, S., \& Griffiths, M. D. (2017). The relationship between addictive use of social media, narcissism, and self-esteem: Findings from a large national survey. Addictive Behaviors, 64, 287-293. https://doi.org/10.1016/j. addbeh.2016.03.006.

Bean, C., \& Forneris, T. (2016). Examining the importance of intentionally structuring the youth sport context to facilitate positive youth development. Journal of Applied
Sport Psychology, 28(4), 410-425. https:// doi.org/10.1080/10413200.2016.116476 4.

Bowen, D. J., Neill, J. T., \& Crisp, S. J. R. (2016). Wilderness adventure therapy effects on the mental health of youth participants. Evaluation and Program Planning, 58, 49-59. https://doi.org/10.1016/j. evalprogplan.2016.05.005.

Branden, N. (1994). The six pillar of self esteem. New York, NY: Bantam Book Publishing History.

Cameron, J. J., \& Granger, S. (2019). Does self-esteem have an interpersonal imprint beyond self-reports? A meta- analysis of self-esteem and objective interpersonal indicators. Personality and Social PsychologyReview, 23(1), 73-102. https:// doi.org/10.1177/1088868318756532.

Connelly, D., \& Rotella, R. J. (1991). The social psychology of assertive communication: issues in teaching assertiveness skills to athletes. Human Kinetics Journal, 5(1), 73-87. https://doi.org/10.1123/tsp.5.1.73.

Coopersmith, S. (1967). The antecedents of self esteem. San Francisco, CA: Freeman Press.

Corey, G. (2009). Teori dan praktek konseling dan psikoterapi. [The theory and practice of counseling and psychotherapy]. Bandung: PT Refika Aditama.

Dehnavi, F., \& Ebrahimi, M. I. (2016). Effect of assertiveness skills training on the level of aggression in high school first grade female students in Qorveh city. International Journal of Humanities and Cultural Studies, March(Special Issue), 1421-1434. http://ijhcs.com/index.php/ ijhcs/article/view/2295.

DiGiuseppe, R., Venezia, R., \& Gotterbarn, R. (2019). What is cognitive behavior therapy? In S. G. Little \& A. AkinLittle (Eds.). Behavioral interventions in schools: Evidence-based positive strategies (School Psychology Book Series). Michigan: American 
Psychological Association, pp. 325-350. https://doi.org/10.1037/0000126-018.

Ghahramani, M. H., Besharat, M. A., \& Naghipour, B. (2011). An examination of the relationship between perfectionism and self-esteem in a sample of student athletes. Procedia - Social and Behavioral Sciences, 30, 1265-1271. https://doi. org/10.1016/j.sbspro.2011.10.245.

Harris, M. A., Guo, J., Mcadams, D. P., Garniervillarreal, M., \& Trzesniewski, K. H. (2017). Parental co-construction of 5 to 13 year-olds' global self-esteem through reminiscing about past events. Child Development, 88(6), 1810-1822. https:// doi.org/10.1111/cdev.12944.

Huang, C., Chen, Y., Greene, L., Cheung, S., \& Wei, Y. (2019). Resilience and emotional and behavioral problems of adolescents in China: Effects of a short-term and intensive mindfulness and life skills training. Children and Youth Services Review, 100(C), 291-297. https://doi. org/10.1016/j.childyouth.2019.03.015.

Karagozoglu, S., Kahve, E., Koc, O., \& Adamisoglu, D. (2008). Self esteem and assertiveness of final year Turkish university students. Nurse Education Today, 28(5), 641-649. https://doi. org/10.1016/j.nedt.2007.09.010.

Kearns, A., Wright, V., Abrams, L., \& Hazley, B. (2017). Slum clearance and relocation: a reassessment of social outcomes combining short-term and long-term perspectives. Housing Studies, 34(2), 1-25. https://doi.org/10.1080/02673037.2 017.1409342 .

Kia, S., Shabani, H., Ahghar, G., \& Modanloo, M. (2016). The effect of assertiveness training on first-grade schoolgirls' selfesteem in Tehran. Iranian Journal of Psychiatric Nursing, 4(1), 38-46. http:// ijpn.ir/article-1-724-en.html.

Lynch, R. T., \& Gussel, L. (1996). Disclosure and self-advocacy regarding disability-related needs: strategies to maximize integration in postsecondary education. Journal of Counseling and Development, 74(4), 352-357. https://doi. org/10.1002/j.1556-6676.1996.tb01879.x.

Mann, M. M., Hosman, C. M. H., Schaalma, H. P., \& Vries, N. K. De. (2004). Self-esteem in a broad-spectrum approach for mental health promotion. Health Education Research, 19(4), 357-372. https://doi. org/10.1093/her/cyg041.

Marzuki, M., Miftahuddin, M., \& Murdiono, M. (2020). Multicultural education in salaf pesantren and prevention of religious radicalism in Indonesia. Cakrawala Pendidikan, 39(1), 12-25. https://doi. org/10.21831/cp.v39i1.22900.

Masselink, M., Roekel, E., \& Oldehinkel, A. . (2018). Self-esteem in early adolescence as predictor of depressive symptoms in late adolescence and early adulthood: The mediating role of motivational and social factors. Journal of Youth and Adolescence, 47(5), 932-946. https://doi.org/10.1007/ s10964-017-0727-z.

Moksnes, U. K., \& Reidunsdatter, R. J. (2019). Self-esteem and mental health in adolescents-level and stability during a school year. Norsk Epidemiologi, 28(8), 59-67. https://doi.org/10.5324/nje.v28i12.3052 .

Murk, C. J. (2006). Self-esteem research, theory, and practice. New York, NY: Springer Publishing Company.

Murray, S. L., \& Holmes, J. G. (2000). Seeing the self through a partner's eyes: why selfdoubts turn into relationship insecurities. In A. Tesser, R. B. Felson, \& J. M. Suls (Eds.). Psychological perspectives on self and identity. Washington, DC: American Psychological Association, pp. 173-197. https://doi.org/10.1037/10357-007.

Nesrin, İ., Sukut, Ö., Uta, L., \& Batmaz, M. (2016). The effect of nurse education on the self-esteem and assertiveness of nursing students: A four-year longitudinal study. Nurse Education Today, 39, 72-78. https:// doi.org/10.1016/j.nedt.2015.12.026. 
Newman, M. G., LaFreniere, L. L., \& Shin, K. E. (2017). Cognitive-behavioral therapies in historical perspective. New York, NY: Oxford University Press.

Nur, L., Nurani, L. A., Suryana, D., \& Ahmad, A. (2020). Rasch model application on character development instrument for elementary school students. International Journal of Learning, Teaching and Educational Research, 19(3), 437-459. https://doi.org/10.26803/ijlter.19.3.24.

Rokhayati, A., Nur, L., Elan, E., \& Gandana, G. (2017). Tactical approach to increase motivation for learning students on physical education teaching in primary schools. IOP Conference Series: Materials Science and Engineering, 180(1), 1-6. https://doi.org/10.1088/17426596/755/1/011001.

Obikwelu, C. L. (2015). Effect of need-focused cognitive restructuring intervention programme on the self-esteem and selfefficacy of recidivist inmates in the prisons in Nigeria (Doctoral Dissertation, University of Nigeria). https://oer.unn. edu.ng/read/effect-of-need-focusedcognitive-restructuring-interventionprogramme-on-the-self-esteem-and-selfefficacy-of-recidivist-inmates-in-theprisons-in-nigeria? $r d r=1$.

Orth, U., Erol, R. Y., \& Luciano, E. C. (2018). Development of self-esteem from age 4 to 94 years: a meta-analysis of longitudinal studies. Psychological Bulletin, 144(10), 1045-1080. https://doi.org/10.1037/ bul0000161.

Parray, W. M., \& Kumar, S. (2017). Impact of assertiveness training on the level of assertiveness, self-esteem, stress, psychological well-being and academic achievement of adolescents. Indian Journal of Health and Well-Being, 8(12), 1476-1480. http://www.iahrw.com/index. php/home/journal_detail/19\#lis.

Radtke, S. R., Strege, M. V, \& Ollendick, T. H. (2020). Exposure therapy for children and adolescents with social anxiety disorder. In T. Peris, E. Storch, \& J. McGuire
(Eds.). Exposure therapy for children with anxiety and OCD: Clinician's guide to integrated treatment. USA: Academic Press. https://doi.org/10.1016/B978-0-12815915-6.00009-3.

Rees, S., \& Graham, R. S. (1991). Assertion training: How to be who you really are? New York, NY: Routledge.

Ronningstam, E. (2017). Intersect between self-esteem and emotion regulation in narcissistic personality disorderimplications for alliance building and treatment. Borderline Personality Disorder and Emotion Dysregulation, 4(3), 1-13. https://doi.org/10.1186/ s40479-017-0054-8.

Seart, A. G. (2003). The effect of an assertiveness training on the assertiveness and self esteem level of $5^{\text {th }}$ grade children (Master Thesis, Middle East Technical University).

Solehuddin, M., \& Budiman, N. (2019). Multicultural competence of prospective preschool teachers in predominantly Muslim country. Cakrawala Pendidikan, 38(3), 438-451. https://doi.org/10.21831/ cp.v38i3.25033.

Vatankhah, H., Daryabari, D., Ghadami, V., \& Naderifar, N. (2013). The effectiveness of communication skills training on selfconcept, self-esteem and assertiveness of female students in guidance school in Rasht. Procedia - Social and Behavioral Sciences, 84, 885-889. https://doi. org/10.1016/j.sbspro.2013.06.667.

Widodo, A. S., \& Pratitis, N. T. (2013). Harga diri dan interaksi sosial ditinjau dari status sosial ekonomi orang tua. [Selfesteem and social interactions in terms of the socioeconomic status of parents]. Jurnal Psikologi Indonesia, 2(2), 131138. https://doi.org/10.30996/persona. v2i2.100.

Windaniati, W. (2013). Meningkatkan selfesteem siswa melalui teknik assertive training pada siswa kelas XI TMO 1 SMK Negeri 7 Semarang. [Improving students' self-esteem through training assertive 
techniques in class XI TMO 1 student of SMK Negeri 7 Semarang]. Jurnal Penelitian Pendidikan, 30(2), 173-180. https://doi.org/10.15294/jpp.v30i2.5679.
Yadav, P. \& Iqbal, N. (2009). Impact of life skill training on self-esteem, adjustment and empathy among adolescents. Journal of the Indian Academy of Applied Psychology, 35(Special Issue), 61-70. 